Volume 1 Issue 2, July-December 2020: pp.78-92.

Faculty of Law, Universitas Lampung, Bandar Lampung, Indonesia.

http://jurnal.fh.unila.ac.id/index.php/ip

P-ISSN: 2723-2638

E-ISSN: $2745-9314$

\title{
Pertanggungjawaban Pidana Terhadap Anak Sebagai Pelaku Kejahatan Kesusilaan Secara Berlanjut
}

\section{Continuous Criminal Accountability of Children as Perpetrators of Crimes of Decency}

\author{
Angga Hardiansyah \\ anggahardiansyah1313@gmail.com
}

Fakultas Hukum Universitas Lampung

Submitted: Jul 22, 2020; Reviewed: August 3, 2020; Accepted: Okt 15, 2020

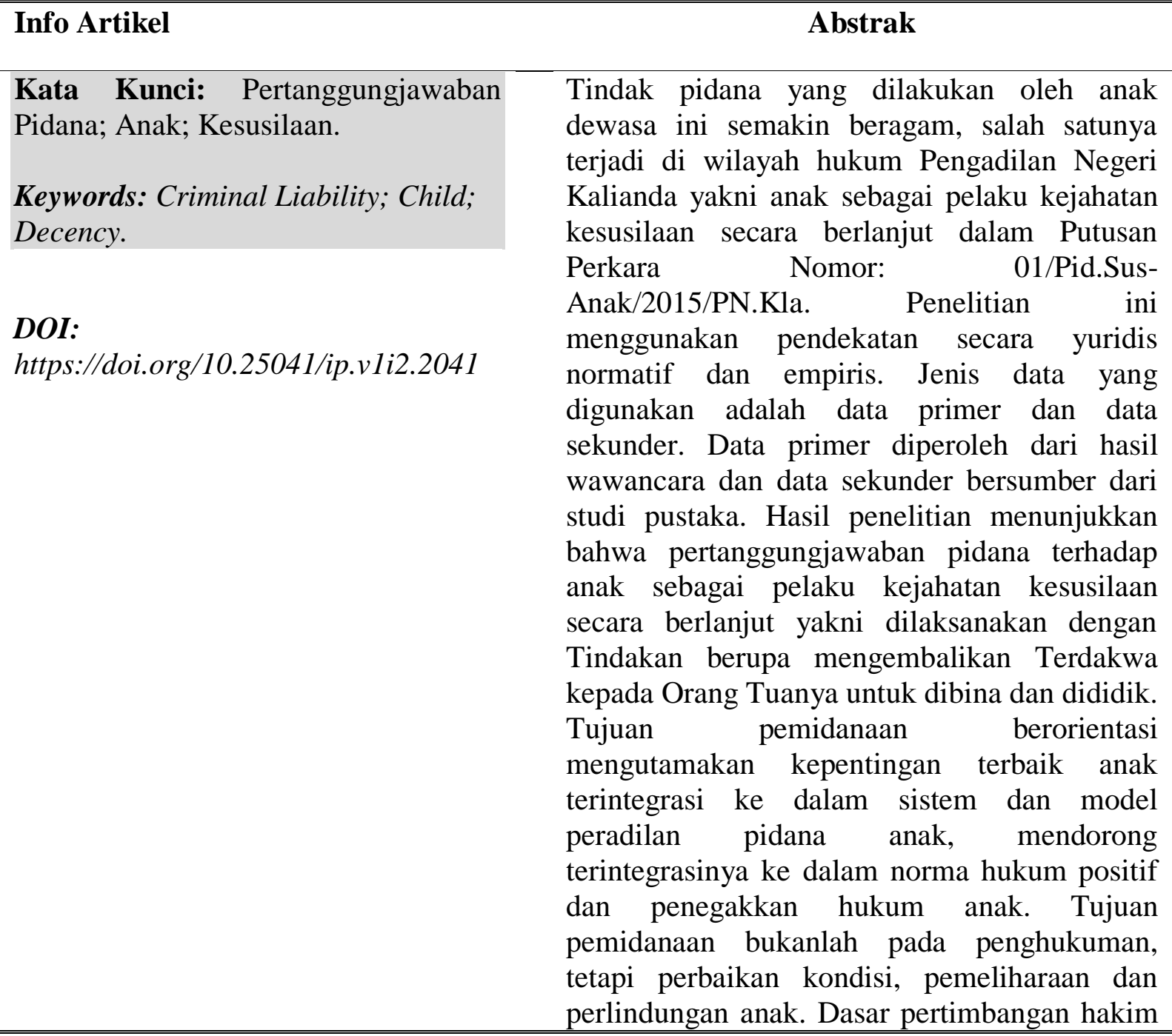


dalam menjatuhkan sanksi pidana adalah dakwaan Jaksa, tujuan pemidanaan, hal-hal yang meringankan dan memberatkan, serta menerapkan beberapa teori-teori tujuan hukum yakni kepastian hukum, kemanfaatan dan keadilan hukum. Saran dalam penelitian ini adalah Hakim sebaiknya lebih memaksimalkan pidana yang dijatuhkan kepada setiap pelaku kejahatan terhadap anak, mengingat bahwa kejahatan terhadap anak di Indonesia terus meningkat sehingga hal ini dapat menjadi salah satu pertimbangan hakim dalam memberikan pidana maksimum terhadap pelaku tindak pidana kesusilaan terhadap anak.

\begin{tabular}{l} 
Abstract \\
Crimes committed by children today are \\
increasingly diverse, one of which occurs in the \\
jurisdiction of the Kalianda District Court, \\
namely children as perpetrators of decency in \\
the Decision on the Case of Number: \\
O1/Pid.Sus-Anak/2015/PN.Kla. This research \\
uses a normative and empirical juridical \\
approach. The type of data used is primary \\
data and secondary data. Primary data were \\
obtained from interviews and secondary data \\
sourced from literature study. The results \\
showed that criminal liability against children \\
as perpetrators of decency was continuously \\
carried out with actions in the form of \\
returning the Defendant to his parents to be \\
nurtured and educated. The aim of criminal \\
justice is to focus on the best interests of \\
children integrated into the system and model \\
of juvenile criminal justice, promoting \\
integration into positive legal norms and the \\
enforcement of child law. The purpose of \\
punishment is notpunishment, but improvement \\
in conditions, care and protection of children. \\
The basis for judges' legal considerations in \\
imposing criminal sanctions is the prosecutor's \\
indictment, the purpose of punishment, things \\
that are lightening and burdensome, as well as \\
applying several theories of legal objectives \\
namely legal certainty, usefulness and legal \\
justice. Suggestions in this study are that \\
Judges should maximize the penalties imposed \\
on each perpetrator of crimes against children, \\
bearing in mind that crimes against children in \\
\hline
\end{tabular}


Indonesia continue to increase so that this can be one of the judges' considerations in providing maximum crimes against perpetrators of moral offenses against children.

\section{A. Pendahuluan}

Hukum mempunyai kehendak yang amat mulia, hukum apabila diartikan hanya sebatas peraturan perundang-undangan, maka akan membuat masalah dengan manusia untuk mencapai rasa bahagia karena manusia mampu mendudukan manusia sebagai mahluk yang sempurna. ${ }^{1}$ Pembinaan, pengembangan dan perlindungan anak memerlukan peran serta masyarakat, baik lembaga perlindungan anak, lembaga keagamaan, lembaga swadaya masyarakat, organisasi kemasyarakatan, organisasi sosial, dunia usaha, media massa atau lembaga pendidikan. Perlunya pengawasan dari orang tua serta pendidikan keagamaan sejak dini bagi kalangan remaja khususnya bagi anak di bawah umur, adalah salah satu faktor penting dalam ikut mencegah dan meminimalisir terjadinya kekerasan, pelecehan terhadap anak di bawah umur. ${ }^{2}$ Anak adalah amanah dan karunia Tuhan Yang Maha Esa yang dalam dirinya juga melekat harkat dan martabat sebagai manusia seutuhnya. Anak adalah tunas, potensi, dan generasi muda penerus cita-cita perjuangan bangsa, memiliki peran strategis dan mempunyai ciri dan sifat khusus yang menjamin kelangsungan eksistensi bangsa dan negara pada masa depan. ${ }^{3}$ Perlindungan hukum terhadap anak yang berhadapan dengan hukum merupakan kewajiban utama bagi setiap negara. ${ }^{4}$ Apabila anak melakukan kesalahan dan tindak pidana, maka anak sudah sepatutnya mendapatkan perlindungan dan perlakuan khusus dalam hal proses peradilannya sebagaimana yang diatur oleh Undang-Undang Nomor 11 Tahun 2012 tentang Sistem Peradilan Pidana Anak. Untuk itu, dalam penjatuhan hukuman terhadap anak diperlukan perlindungan hukum yang dapat menjamin hak-hak anak terpenuhi. ${ }^{5}$

Nilai-nilai budaya bangsa yang ingin diraih adalah menegakkan hukum dan keadilan berdasarkan Pancasila. ${ }^{6}$ Hukum merupakan sebuah kata yang masih abstrak, maka sebagai perwujudannya dengan dikodifikasikannya suatu hukum ke dalam tulisan yang disebut peraturan perundang-undangan ${ }^{7}$ Oleh sebab itu, Pendekatan sistem peradilan pidana haruslah menyesuaikan dengan karakter masyarakat di mana kejahatan itu terjadi, karena faktor-faktor penyebab terjadinya kejahatan itu sangatlah beragam terutama pada kondisi psikologi anak

\footnotetext{
${ }^{1}$ Larensius Arliman S, "Pendidikan Paralegal Kepada Masyarakat Sebagai Bentuk Perlindungan Anak Yang Berkelanjutan," UIR LAW REVIEW, Vol. 1, No. 01 (April 25, 2017): 63-76, https://doi.org/10.25299/ulr.2017.1.01.153. hlm 64.

${ }^{2}$ Laurensius Arliman et al., "Reformasi Penegakan Hukum Kekerasan Seksual Terhadap Anak Sebagai Bentuk Perlindungan Anak Berkelanjutan Reform Of Law Enforcement Of Sexual Violence To Children As The Form Of Sustainable Children Protection," Kanun Jurnal Ilmu Hukum Vol. 19, No. 2 (August 27, 2311): 305-326, http://www.jurnal.unsyiah.ac.id/kanun. hlm 179.

${ }^{3}$ :Okky Chahyo Nugroho, "Peran Balai Pemasyarakatan Pada Sistem Peradilan Pidana Anak Ditinjau Dalam Perspektif Hak Asasi Manusia," Jurnal HAM 8, No. 2 (December 15, 2017): 161-74, https://ejournal.balitbangham.go.id/index.php/ham/article/view/356. hlm 162.

${ }^{4}$ Hendricus Andrianto and Nur Rochaeti, "Implementasi Diversi Terhadap Anak Yang Berhadapan Dengan Hukum Di Polres Pati," DIPONEGORO LAW JOURNAL, vol. 5, No. 3 (Program Studi S1 Ilmu Hukum, Fakultas Hukum, Universitas Diponegoro, July 11, 2016): 1-10, https://ejournal3.undip.ac.id/index.php/dlr/article/view/12535. hlm 4.

${ }^{5}$ Nyoman Et Al., "Perlindungan Hukum Terhadap Anak Sebagai Pelaku Tindak Pidana Narkotika," Kertha Wicara: Journal Ilmu Hukum, Vol. 9, No. 2 (January 13, 2020):1-115, https://ojs.unud.ac.id/index.php/kerthawicara/article/view/53868. hlm 4.

${ }^{6}$ Ariyunus Zai, Taufik Siregar, and Dedy irsan, "Perlindungan Hukum Terhadap Anak Yang Berhadapan Dengan Hukum Dalam Sistem Peradilan Anak (Studi Pada Wilayah Hukum Polres Nias)," JURNAL MERCATORIA, vol. 4, (December 1, 2011): 86-103, http://www.ojs.uma.ac.id/index.php/mercatoria/article/view/610. hlm 89.

7 shandi patria airlangga, "hakikat penguasa dalam negara hukum demokratis the nature of the authorities in a democratic rule of law," cepalo 3, no. 1 (september 17, 2019): 1-10, https://doi.org/10.25041/cepalo.v3no1.1783. hlm 2.
} 
yang sangat labil. ${ }^{8}$ Untuk itu peradilan anak bertujuan memberikan yang paling baik bagi anak, tanpa mengorbankan kepentingan masyarakat dan tegaknya suatu keadilan. Tujuan Peradilan Anak tidak berbeda dengan peradilan lainnya, yaitu memeriksa, memutus dan menyelesaikan perkara anak. Tindak kriminalitas, dan tidak jarang tindak kriminalitas ini dilakukan oleh anak yang masih dibawah umur, ${ }^{9}$ dalam hal ini pelaksanaan pembinaan dan perlindungan terhadap anak, diperlukan dukungan baik yang menyangkut kelembagaan maupun perangkat hukum yang lebih baik dan mewadahi. Unsur perbuatan delinquat bersifat anti sosial dari berbagai tindakan untuk mengamankan masyarakat maka para pelaku kejahatan diberi hukuman yang sesuai dengan perbuatannya dan perbuatan delinguat adalah perbuatan yang merugikan dalam segala aspeknya. ${ }^{10}$ Disamping itu kejahatan yang dilakukan oleh orang dewasa pada umumnya hampir sama dengan yang dilakukan oleh anak-anak pula. Unsur perbuatan delinquat adalah pelanggaran-pelanggaran norma masyarakat. ${ }^{11}$

Menurut Tolib Setiady bahwa berbagai motif kejahatan yang dilakukan anak terjadi karena hal-hal tertentu, sedangkan kualitas setiap motif berbeda-beda, suatu kejahatan yang muncul di permukaan tidak selalu berdiri sendiri, ada suatu gejala yang melatarbelakanginya, seperti berbagai kondisi psikologis maupun sosiologis yang dapat memicu timbulnya kejahatan tersebut dalam segala aspek dan kondisinya. Kejahatan yang dilakukan anak merupakan suatu bentuk penyimpangan dan bertentangan dengan Undang-undang sehingga sebagai akibat perbuatan tersebut seorang anak dapat dipidana. Menurut Sudarto yang di kutip oleh Tolib Setiady menjelaskan bahwa pemidanaan diartikan sebagi menetapkan hukum atau memutuskan tentang hukumnya (berechten). ${ }^{12}$

Fakta sosial sebagai problema yang terjadi bahwa tindak pidana yang dilakukan oleh anak juga terjadi di wilayah hukum Pengadilan Negeri Kalianda. Dalam kasus pada Pengadilan Negeri Kalianda Penetapan Nomor: 01/Pid.Sus-Anak/2015/PN.Kla, terdakwa terdakwa Bayu Setiangga Bin Supriyanto yang masih berumur 16 tahun, telah terbukti secara sah dan meyakinkan bersalah melakukan tindak pidana kesusilaan secara berlanjut terhadap saksi korban Diah Indra Sari Binti Sukamto yang masih berumur 14 tahun. Perbuatan terdakwa melanggar Pasal 81 Ayat (2) Undang-Undang Nomor 35 Tahun 2014 tentang Perubahan Atas Undang-Undang Nomor 23 Tahun 2002 tentang Perlindungan Anak. Majelis Hakim sepakat Menjatuhkan Tindakan berupa mengembalikan Terdakwa Bayu Setiangga Bin Supriyanto kepada Orang Tuanya untuk dibina dan dididik. Penjatuhan sanksi tindakan berupa mengembalikan Terdakwa kepada Orang Tuanya untuk dibina dan dididik terhadap pelaku tindak pidana asusila secara berlanjut terhadap anak di bawah umur tersebut dapat dimintai pertanggungjawabannya, sesuai dengan unsur-unsur tindak pidana, yaitu sehat jiwanya, mengetahui bahwa perbuatannya bertentangan dengan hukum serta mampu mengetahui kehendak sesuai kesadarannya, sehingga dapat dipidana.

Penerapan sanksi pidana terhadap anak pelaku tindak pidana kesusilaan secara berlanjut dalam kasus pada Pengadilan Negeri Kalianda Penetapan Nomor: 01/Pid.SusAnak/2015/PN.Kla dapat dimintai pertanggungjawabannya, sesuai dengan unsur-unsur tindak pidana, yaitu sehat jiwanya, mengetahui bahwa perbuatannya bertentangan dengan hukum serta mampu mengetahui kehendak sesuai kesadarannya, sehingga dapat dipidana oleh

\footnotetext{
${ }^{8}$ Wiwik Afifah, "Pertanggungjawaban Pidana Anak Konflik Hukum," DIH, Jurnal Ilmu Hukum Vol. 10, No. 19, (Pebruari 2014): 48-62 https://media.neliti.com/media/publications/240062-pertanggungjawaban-pidana-anak-konflik-h-1431e76f.pdf. hlm 49.

${ }^{9}$ Ni Made et al., "Implementasi Undang-Undang Nomor 11 Tahun 2012 Tentang Sistem Peradilan Pidana Anak Terhadap Curanmor Yang Dilakukan Oleh Anak Di Kabupaten Buleleng (Studi Kasus Perkara Nomor: B/346/2016/RESKRIM)," Jurnal Komunitas Yustisia, vol. 2, (February 28, 2019): 1-11 https://bulelengkab.bps.go.id. hlm 3.

${ }^{10}$ Bilher Hutahaean, "Penerapan Sanksi Pidana Bagi Pelaku Tindak Pidana Anak" Jurnal Yudisial, vol. 6, (March 11, 2013): 64-79, https://doi.org/10.29123/JY.V6I1.119. hlm 65.

${ }^{11}$ P.A.F. Lamintang, Dasar-Dasar Hukum Pidana Indonesia, Bandung: Citra Aditya Bakti, (1997), hlm. 16.

12 Tolib Setiady, Pokok-Pokok Hukum Penitensier Anak Indonesia, Bandung: Alfabeta, (2010), hlm. 19.
} 
Hakim. Tujuan Majelis Hakim telah Menjatuhkan Tindakan berupa mengembalikan Terdakwa Bayu Setiangga Bin Supriyanto kepada Orang Tuanya untuk dibina dan dididik sesuai dengan konsep tujuan pemidanaan yakni bukanlah suatu pembalasan melainkan pembinaan bagi terdakwa yang telah berbuat salah dan agar dapat mempertanggungjawabkan perbuatannya.

Secara yuridis Sanski Tindakan berupa mengembalikan Terdakwa Bayu Setiangga Bin Supriyanto kepada Orang Tuanya untuk dibina dan dididik dalam kasus pada Pengadilan Negeri Kalianda Putusan Nomor: 01/Pid.Sus-Anak/2015/PN.Kla yakni anak sebagai pelaku tindak pidana kesusilaan secara berlanjut tersebut memang sudah memenuhi ketentuan Pasal 81 Ayat (2) Undang-Undang Nomor 35 Tahun 2014 tentang Perubahan Atas Undang-Undang Nomor 23 Tahun 2002 tentang Perlindungan Anak yang menyatakan perlindungan hukum kepada anak korban perkosaan. ${ }^{13}$ Namun, terkadang putusan hakim tidak pernah mencapai pidana yang maksimum seperti yang diancamkan dalam undang-undang. Sanksi yang dijatuhkan terhadap pelaku dinilai belum tepat jika dilihat dari akibat perbuatan yang dilakukan pelaku tindak pidana kesusilaan secara berlanjut sehingga belum sepenuhnya memenuhi rasa keadilan bagi korban. Putusan Hakim yang tidak mencapai pidana maksimum seperti yang diancamkan dalam undang-undang, perbuatan terdakwa dalam perkara tersebut juga merupakan perbuatan berulang yang tidak hanya 1 (satu) kali dilakukan namun Majelis Hakim Menjatuhkan Tindakan berupa mengembalikan Terdakwa Bayu Setiangga Bin Supriyanto kepada Orang Tuanya untuk dibina dan dididik. Hal ini tentu menimbulkan permasalahan dalam pemidanaan dalam mencapai keadilan yang menginginkan pelaku tindak pidana kesusilaan secara berlanjut diberikan hukuman yang seimbang dengan akibat perbuatannya, hal inilah peranan Hakim sangat penting sebagai penengah di antara pihakpihak yang berperkara.

Masalah sosial yang terjadi juga bahwa penjatuhan pidana terhadap tindak pidana kesusilaan secara berlanjut dapat menimbulkan ketidakadilan secara substantif maupun prosedural baik bagi korban maupun keluarganya hal ini karena tindak pidana kesusilaan secara berlanjut sangat berdampak buruk bagi perkembangan korban terlebih bahwa korban masih pelajar dan memiliki masa depan namun terhenti akibat perbuatan terdakwa. Tuntutan Jaksa yang menuntut selama 7 (tujuh) tahun pidana penjara dan 6 (enam) bulan dengan dikurangi seluruhnya masa telah dijalaninya dengan perintah terdakwa tetap ditahan dan didenda sebesar Rp 60.000.000,- (enam puluh juta rupiah) subsidair 3 (tiga) bulan kurungan namun Majelis Hakim hanya memberikan vonis Menjatuhkan Tindakan berupa mengembalikan Terdakwa Bayu Setiangga Bin Supriyanto kepada Orang Tuanya untuk dibina dan dididik. Hal ini tentunya melukai rasa keadilan bagi korban dan keluarganya karena selain mengalami derita, depresi, dan trauma yang besar di masa depan korban juga menanggung beban sosial. Pidana ini dirasakan terlalu ringan bila dibandingkan dengan derita, depresi, dan trauma yang besar di masa depan korban.

Berdasarkan Indentifikasi masalah di atas, permasalahan penulisan ini adalah menganalisa pertanggungjawaban pidana terhadap anak sebagai pelaku kejahatan kesusilaan secara berlanjut dan apa yang menjadi dasar pertimbangan hukum hakim dalam menjatuhkan sanksi pidana terhadap anak sebagai pelaku kejahatan kesusilaan secara berlanjut. Ruang lingkup dalam penelitian ini di batasi pada kajian hukum pidana yang mengkaji terkait dengan pertanggungjawaban pidana terhadap anak sebagai pelaku kejahatan kesusilaan secara berlanjut. Penelitian ini juga mengkaji terkait dengan dasar pertimbangan hukum hakim dalam menjatuhkan sanksi pidana terhadap anak sebagai pelaku kejahatan kesusilaan secara berlanjut. Studi penelitian ini adalah Putusan Perkara Nomor : 01/Pid.Sus-Anak/2015/PN.Kla.

${ }^{13}$ H Dudung Mulyadi, "Perlindungan Hukum Bagi Anak Korban Perkosaan Dalam Peradilan Anak," Jurnal Ilmiah Galuh Justisi, vol. 6, (November 19, 2018): 170-183, https://jurnal.unigal.ac.id/index.php/galuhjustisi/article/view/1712. hlm 179. 
Pendekatan masalah dalam penelitian ini menggunakan pendekatan yuridis normatif dan pendekatan yuridis empiris. ${ }^{14}$

\section{B. Pembahasan}

\section{Pengertian Anak yang berhadapan dengan Hukum}

Ditinjau dari aspek yuridis maka pengertian "anak" di mata hukum positif Indonesia lazim diartikan sebagai orang yang belum dewasa (minderjarig/person under age). ${ }^{15}$ UndangUndang Nomor 11 Tahun 2012 tentang Sistem Peradilan Pidana Anak mengklarifikasikan pengertian anak yang berhadapan dengan hukum adalah orang yang dalam perkara telah mencapai umur delapan tahun, tetapi belum mencapai umur delapan belas tahun dan belum pernah kawin. Berbagai undang-undang mengatur batas usia anak secara berbeda-beda. Perbedaan batasan yang diberikan berkaitan erat dengan pokok persoalan yang diatur. ${ }^{16}$ Anak yang berhadapan dengan hukum adalah anak yang telah mencapai usia 12 (dua belas) tahun tetapi belum mencapai usia 18 (delapan belas) tahun dan belum menikah:

a. Yang diduga, disangka, didakwa, atau dijatuhi pidana karena melakukan tindak pidana;

b. Yang menjadi korban tindak pidana atau yang melihat dan/atau mendengar sendiri terjadinya suatu tindak pidana. ${ }^{17}$

Anak yang berhadapan dengan hukum dapat juga dikatakan sebagai anak yang terpaksa berkontak dengan sistem pengadilan pidana karena:

a) Disangka, didakwa, atau dinyatakan terbukti bersalah melanggar hukum; atau Telah menjadi korban akibat perbuatan pelanggaran hukum yang dilakukan orang/kelompok orang/lembaga/negara terhadapnya; atau

b) Telah melihat, mendengar, merasakan, atau mengetahui suatu peristiwa pelanggaran hukum.

Sehingga berdasarkan ruang lingkupnya maka anak yang berhadapan dengan hukum dapat dibagi menjadi:

1) Pelaku atau tersangka tindak pidana;

2) Korban tindak pidana;

3) Saksi suatu tindak pidana. ${ }^{18}$

Pada dasarnya terlihat tidak etis apabila tindak pidana yang dilakukan oleh anak disebut dengan kejahatan, karena pada dasarnya anak-anak memiliki kondisi kejiwaan yang sangat labil, proses kemantapan psikis menghasilkan sikap kritis, agresif dan menunjukkan tingkah laku yang cenderung bertindak mengganggu ketertiban umum. ${ }^{19}$ Anak yang berkonflik dengan hukum dapat juga diartikan dengan anak yang mempunyai permasalahan karena suatu perbuatan yang bertentangan dengan hukum, atau bisa juga dikatakan bahwa anak yang

\footnotetext{
${ }^{14}$ Soerjono Soekanto, Pengantar Penelitian Hukum, Jakarta: UI Press, (1986), hlm. 9.

${ }^{15}$ Selamat Widodo, "Diversi Sebagai Bentuk Perlindungan Hak Asasi Anak Yang Berhadapan Dengan Hukum (Studi Di Pengadilan Negeri Purwokerto)," Jurnal Kosmik Hukum, Vol., 17, no. 1 (January 30, 2017): 50-61 https://doi.org/10.30595/kosmikhukum.v17i1.2318. hlm 52.

${ }_{16}$ Mayadina Rohmi Musfiroh, "Pernikahan Dini Dan Upaya Perlindungan Anak Di Indonesia." De Jure : Jurnal Hukum dan Syari'ah Vol. 8, no. 2 (2016): 64-73, https://doi.org/10.18860/j-fsh.v6i1.3192. hlm 66.

${ }^{17}$ Maidin Gultom, Perlindungan Hukum Terhadap Anak dalam Sistem Peradilan Pidana Anak di Indonesia, Refika Aditama, Bandung, 2008, hlm. 39. lihat juga dalam Apong Herlina, dkk, Perlindungan terhadap Anak yang Berhadapan dengan Hukum, Buku Saku untuk Polisi, Jakarta: Unicef, (2004), hlm. 17.

${ }^{18}$ Sri Widoyanti, Anak dan Wanita dalam Hukum, Jakarta: Pradya Paramita, (1984), hlm.52

19 Dony Pribadi, "Perlindungan Terhadap Anak Berhadapan Dengan Hukum," Jurnal Hukum Volkgeist Vol. 3, no. 1 (December 14, 2018): 15-28, https://doi.org/10.35326/volkgeist.v3i1.110. hlm 19.
} 
berkonflik dengan hukum adalah anak nakal. ${ }^{20}$ Kenakalan anak (juvenile delinquency) bukan kenakalan yang dimaksud dalam Pasal 489 KUHP. Juvenile artinya young, anak-anak, anak muda, ciri karakteristik pada masa muda sifat-sifat khas pada periode remaja, sedangkan delinguency artinya doing wrong, terabaikan/mengabaikan, yang kemudian diperluas artinya menjadi jahat, a-sosial, kriminal, pelanggar aturan, pembuat ribut, pengacau, penteror, tidak dapat diperbaiki lagi, durjana, dursila, dan lain-lain. ${ }^{21}$

\section{Pertanggungjawaban Pidana Terhadap Anak Sebagai Pelaku Kejahatan Kesusilaan Secara Berlanjut}

Hakim dalam menjatuhkan putusan terhadap anak sebagai pelaku kejahatan kesusilaan secara berlanjut juga ditentukan berdasar pada kesalahan pembuat (liability based on fault), dan bukan hanya dengan dipenuhinya seluruh unsur suatu tindak pidana. Hakim bertanggungjawab tidak hanya menerapkan hukum tertulis saja tetapi juga harus dapat menciptakan hukum atau menemukan hukum berdasarkan pandangan dan nilai-nilai hukum yang hidup dalam masyaraka. ${ }^{22}$ Dengan demikian, kesalahan ditempatkan sebagai faktor penentu pertanggungjawaban pidana dan tidak hanya dipandang sekedar unsur mental dalam tindak pidana. Unsur-unsur yang mengakibatkan dipidananya seorang terdakwa adalah mampu bertanggungjawab, syarat-syarat seorang mampu bertanggungjawab adalah factor akal dan faktor kehendak. Faktor akal yaitu dapat membeda-bedakan antara perbuatan yang yang diperbolehkan dan perbuatan yang tidak diperbolehkan. Faktor kehendak yaitu menyesuaikan tingkah lakunya dengan keinsafan atas mana diperbolehkan dan yang tidak diperbolehkan. ${ }^{23}$

Seseorang yang telah memenuhi unsur tindak pidana dan bersifat melawan hukum (formil, materiil), serta tidak ada alasan pembenar, serta mempunyai kesalahan wajib mempertanggungjawabkan perbuatannya seperti halnya dalam Putusan Pengadilan Negeri Kalianda Nomor: 01/Pid.Sus-Anak/2015/PN.Kla bahwa Majelis Hakim sepakat Menjatuhkan Tindakan berupa mengembalikan Terdakwa Bayu Setiangga Bin Supriyanto kepada Orang Tuanya untuk dibina dan dididik. Penjatuhan sanksi tindakan berupa mengembalikan Terdakwa kepada Orang Tuanya untuk dibina dan dididik terhadap pelaku tindak pidana asusila secara berlanjut terhadap anak di bawah umur tersebut dapat dimintai pertanggungjawabannya, sesuai dengan unsur-unsur tindak pidana, yaitu sehat jiwanya, mengetahui bahwa perbuatannya bertentangan dengan hukum serta mampu mengetahui kehendak sesuai kesadarannya, sehingga dapat dipidan.

Berdasarkan fakta hukum dalam Putusan Pengadilan Negeri Kalianda Nomor: 01/Pid.Sus-Anak/2015/PN.Kla terdakwa terbukti bersalah dan memenuhi unsur-unsur pidana serta tidak ditemukan alasan penghapus pidana dalam hal ini baik alasan pembenar maupun alasan pemaaf sehingga dengan demikian dijadikan pertimbangan hakim terhadap terdakwa untuk mampu bertanggung jawab atas perbuatan yang dilakukannya.

Penulis telah melakukan wawancara kepada beberapa pihak dintaranya hakim, akademisi serta LSM Lada diantaranya:

1) Hakim Pengadilan Negeri Kalianda (Deka Diana) ${ }^{24}$ menyampaikan bahwa putusan yang dijatuhkan terhadap anak sebagai pelaku kejahatan kesusilaan secara berlanjut dalam Putusan Pengadilan Negeri Kalianda Nomor: 01/Pid.Sus-Anak/2015/PN.Kla telah sesuai dengan hukum acara yang berlaku. Selama proses peradilan baik dari tingkat penyidikan

\footnotetext{
${ }^{20}$ M. Hassan Wadong, Advokasi dan Hukum Perlindungan Anak, Jakarta: Grasindo, (2012), hlm.46

${ }^{21}$ Wagiati Soetodjo, Hukum Pidana Anak, Bandung: Refika Editama, (2006), hlm. 39.

${ }^{22}$ Aghisni Karrota Rizki., "Dasar Pertimbangan di mahkamah militer II-10 SEMARANG) Info Artikel," UL J, vol. 4, No. 1, (2015): 35-55, https://doi.org/10.15294/ULJ.V4I1.7270. hlm 36.

${ }^{23}$ Roeslan Saleh, Pertanggungjawaban Hukum Pidana, Jakarta: Aksara Baru, (1987), hlm. 49

${ }^{24}$ wawancara dengan Deka Diana selaku Hakim Pengadilan Negeri Kalianda tanggal 21 Oktober 2018, pukul 09.30 WIB
} 
hingga tingkat eksekusi terhadap terdakwa dalam keadaan sehat jasmani dan rohani, serta tidak ditemukan alasan penghapus pidana sehingga dengan demikian sebagai pertimbangan hakim maka terdakwa dikategorikan mampu bertanggungjawab atas perbuatan yang dilakukannya sehingga Majelis Hakim Pengadilan Negeri Kalianda yang memeriksa dan mengadili perkara ini berdasarkan keyakinan dengan alat bukti yang cukup, guna mewujudkan cita hukum maka terdakwa yang masih anak-anak harus tetap mendapatkan sanksi.

Putusan Pengadilan Negeri Kalianda Nomor: 01/Pid.Sus-Anak/2015/PN.Kla Terdakwa berdasarkan fakta dan bukti di persidangan maka terdakwa terbukti bersalah dan memenuhi unsur-unsur pidana, melawan perbuatan pidana, mampu bertanggung jawab, dengan sengaja atau kealpaan serta tidak ditemukan alasan penghapus pidana dalam hal ini baik alasan pembenar maupun alasan pemaaf sehingga dengan demikian terdakwa mampu bertanggung jawab atas tindak pidana kesusilaan secara berlanjut sebagaimana diatur dalam Pasal 81 Ayat (2) Undang-Undang Nomor 35 Tahun 2014 jo Pasal 64 Ayat (1) KUHP. ${ }^{25}$

Menelaah pendapat di atas di atas, maka dapat dianalisis bahwa dipidananya anak sebagai pelaku kejahatan kesusilaan secara berlanjut dalam Putusan Pengadilan Negeri Kalianda Nomor: 01/Pid.Sus-Anak/2015/PN.Kla tidak cukup jika Terdakwa hanya memenuhi unsur tindak pidana sebagaimana diatur dalam ketentuan Pasal 81 Ayat (2) Undang-Undang Nomor 35 Tahun 2014 jo Pasal 64 Ayat (1) KUHP. Meskipun telah melakukan perbuatan yang memenuhi unsur-unsur tindak pidana dan bersifat melawan hukum, serta tidak ada alasan pembenar, hal tersebut belum memenuhi syarat bahwa orang yang melakukan tindak pidana harus mempunyai kesalahan. Untuk adanya kesalahan yang mengakibatkan dipidananya terdakwa, maka terdakwa haruslah mempunyai kesalahan, mampu bertanggung jawab, dengan sengaja atau kealpaan, dan tidak ada alasan pemaaf. Terdakwa telah memenuhi kriteria tersebut, sehingga dalam pertimbangan hakim terdakwa harus mempertanggungjawabkan perbuatannya. Dalam Putusan Pengadilan Negeri Kalianda Nomor: 01/Pid.Sus-Anak/2015/PN.Kla nama Terdakwa terbukti bersalah dan memenuhi unsur-unsur pidana serta tidak ditemukan alasan penghapus pidana dalam hal ini baik alasan pembenar maupun alasan pemaaf sehingga dengan demikian dalam pertimbangan hakim terdakwa mampu bertanggung jawab atas tindak pidana kesusilaan secara berlanjut.

Berdasarkan fakta dan bukti di persidangan maka dalam pertimbangan hakim terdakwa mampu bertanggungjawab terhadap perbuatan yang dilakukannya, maka sesuai dengan teori kemampuan bertanggungjawab sedemikian yang membenarkan adanya penerapan suatu upaya pemidanaan, baik dilihat dari sudut umum maupun dari orangnya, Terdakwa terbukti melanggar Pasal 81 Ayat (2) Undang-Undang Nomor 35 Tahun 2014 jo Pasal 64 Ayat (1) KUHP. Penerapan sanksi pidana terhadap anak pelaku tindak pidana kesusilaan secara berlanjut dalam kasus pada Pengadilan Negeri Kalianda Penetapan Nomor: 01/Pid.Sus-Anak/2015/PN.Kla dapat dimintai pertanggungjawabannya, sesuai dengan unsur-unsur tindak pidana, yaitu sehat jiwanya, mengetahui bahwa perbuatannya bertentangan dengan hukum serta mampu mengetahui kehendak sesuai kesadarannya, sehingga dapat dipidana oleh Hakim. Tujuan Majelis Hakim telah Menjatuhkan Tindakan berupa mengembalikan Terdakwa Bayu Setiangga Bin Supriyanto kepada Orang Tuanya untuk dibina dan dididik sesuai dengan konsep tujuan pemidanaan yakni bukanlah suatu pembalasan melainkan pembinaan bagi terdakwa yang telah berbuat salah dan agar dapat mempertanggungjawabkan perbuatannya.

\footnotetext{
${ }^{25}$ wawancara dengan Deka Diana selaku Hakim Pengadilan Negeri Kalianda tanggal 21 Oktober 2018, pukul 09.30 WIB
} 
Berdasarkan pendapat penjabaran di atas, maka peneliti menganalisis bahwa hakim mempertimbangkan kemampuan bertanggungjawabnya, selanjutnya mempertimbangkan hal-hal yang memberatkan dan meringankan, dakwaan Jaksa, pelaku, perbuatan dan korban, yang semuanya melatarbelakangi berat ringannya pidana yang dijatuhkan oleh hakim. Karena berdasarkan dakwaan dan tuntutan jaksa tersebut, hakim mempertimbangkan pidana yang tepat terhadap anak sebagai pelaku kejahatan kesusilaan secara berlanjut. Anak sebagai pelaku kejahatan kesusilaan secara berlanjut tersebut termasuk seseorang yang dapat diakategorikan mampu bertanggungjawab, karena ada unsur kesengajaan, dimana pelaku melakukan perbuatannya dalam keadaan sadar dan sehat jasmani serta tahu bahwa perbuatan yang dilakukan adalah suatu penyimpangan.

2) Koordinator Penanganan Kasus dan Pengorganisiran LSM LADA Bandar Lampung (Lukman) menjelaskan bahwa pertimbangan yang digunakan oleh penegak hukum sebagaimana dalam Putusan Pengadilan Negeri Kalianda Nomor: 01/Pid.SusAnak/2015/PN.Kla, terhadap Terdakwa oleh Jaksa Penuntut Umum di dakwa dengan menggunakan Pasal 81 Ayat (2) Undang-Undang Nomor 35 Tahun 2014 jo Pasal 64 Ayat (1) KUHP. Bahwa selama proses hukum baik dari tingkat penyidikan hingga tingkat eksekusi terhadap terdakwa ternyata dalam keadaan sehat jasmani dan rohani (tidak termasuk kualifikasi pasal 44 KUHP) serta tidak ditemukan alasan penghapus pidana dalam hal ini baik alasan pembenar maupun alasan pemaaf sehingga dengan demikian terdakwa mampu bertanggung jawab terhadap perbuatan yang dilakukannya. Majelis Hakim sepakat Menjatuhkan Tindakan berupa mengembalikan Terdakwa Bayu Setiangga Bin Supriyanto kepada Orang Tuanya untuk dibina dan dididik. ${ }^{26}$

Berdasarkan pendapat narasumber di atas, maka peneliti menganalisis bahwa bahwa pertimbangan yang digunakan oleh penegak hukum terhadap Terdakwa adalah orang yang mampu bertanggungjawab terhadap perbuatan yang dilakukannya sehingga berdasarkan hal tersebut sebagaimana azas "tiada pidana tanpa kesalahan" dihubungkan dengan fakta-fakta yang terungkap dipersidangan dalam hal ini terdapat 4 (empat) alat bukti sebagaimana Pasal 184 KUHAP sehingga berdasarkan hal tersebut berdasarkan ketentuan Pasal 183 KUHAP, Majelis Hakim Menjatuhkan Tindakan berupa mengembalikan Terdakwa Bayu Setiangga Bin Supriyanto kepada Orang Tuanya untuk dibina dan dididik. Jaksa Penuntut Umum dalam menuntut perkara tindak pidana kesusilaan secara berlanjut melihat fakta-fakta di persidangan, kemudian dihubungkan dengan Pasal-Pasal yang didakwakan dan sesuai dengan kasus yang ada, kemudian dicermati dalam Kitab Undang-Undang Hukum Pidana. Karena itu jaksa menuntutnnya dengan undang-undang tersebut dan penuntutannya dianggap sesuai dengan hukuman yang dijatuhkan, karena telah memkai undang-undang tersebut.

Berdasarkan hasil wawancara dengan Lukman selaku Koordinator Penanganan Kasus dan Pengorganisiran LSM LADA Bandar Lampung menjelaskan bahwa anak sebagai pelaku kejahatan kesusilaan secara berlanjut secara umum merupakan suatu kejahatan yang dilakukan oleh anak yakni berupa delinkuen sosiologis dan delinkuen individual. Pembagian ini berdasarkan atas sikap dan corak perbuatan. Delinkuen sosiologis adalah suatu keadaan dimana seorang anak memusuhi seluruh konteks kemasyarakatan kecuali konteks komunitasrnya sendiri dalam kondisi ini kebanyakan anak tidak merasa bersalah bila merugikan orang lain, selama tidak merugikan komunitasnya sendiri. Delinkuen individual adalah komisi dimana anak memusuhi semua orang bahkan kedua orang tuanya sendiri yang biasanya hubungan tersebut makin memburuk karena bertambahnya usia. Kedua bentuk

\footnotetext{
${ }^{26}$ Hasil wawancara dengan Lukman selaku Koordinator Penanganan Kasus dan Pengorganisiran LSM LADA Bandar Lampung tanggal 26 Oktober 2018, pukul 14.15 WIB
} 
delinkuen tersebut sama-sama merugikan dan meresahkan masyarakat, bila ditinjau dari mulanya terjadi, keduanya saling menunjang dan diperkembangkan anak delinkuen bisa bermula dari keadaan intern keluarga yang kernudian dikembangkan dan ditunjang oleh pergaulan sekitar tempat anak tumbuh dan berkembang bersama teman-temannya yang juga bisa membentuk seorang anak menjadi delinkuen. ${ }^{27}$

Sehubungan dengan hal di atas, menurut Lukman selaku Koordinator Penanganan Kasus dan Pengorganisiran LSM LADA Bandar Lampung menambahkan bahwa pertimbangan aparat penegak hukum dalam menerapkan sanksi pidana terhadap anak sebagai pelaku kejahatan kesusilaan secara berlanjut melihat faktor psikologis, keadaan ekonomis dan lingkungan seorang anak dapat dimintai pertanggungjawabannya apabila ada unsur kesengajaan yang dilakukan anak sebagai pelaku kejahatan kesusilaan secara berlanjut serta melawan hukum. Dalam hal ini, perbuatan pelaku pada dasarnya termasuk melawan hukum karena telah terjadi kegiatan tindak pidana kesusilaan secara berlanjut, namun secara psikologis anak tersebut tidak mengetahui dan mengerti atas perbuatannya. Terjadinya unsur kesengajaan karena tujuan akhir dari tindakan pelaku adalah terjadinya tindak pidana, namun dalam memberikan pertimbangan pun juga harus melihat berbagai aspek baik aspek hukum, psikologis, dan kemanusiaan. Melihat pelaku yang masih anak dibawah umur maka hal ini tentunya mensyaratkan mengenai bentuk rehabilitasi dan pembinaan khusus terhadap pelaku untuk dapat untuk mengembangkan kontrol diri. ${ }^{28}$

Berdasarkan hasil wawancara dengan Eddy Rifai selaku Dosen Bagian Hukum Pidana Fakultas Hukum Universitas Lampung menjelaskan bahwa dalam penjatuhan pidana terhadap anak sebagai pelaku kejahatan kesusilaan secara berlanjut dalam Perkara Nomor 01/Pid.SusAnak/2015/PN.Kla, Hakim tidak dapat mengesampingkan dakwaan Jaksa. Dakwaan Jaksa merupakan salah satu dasar pertimbangan bagi hakim sebelum menjatuhkan pidana. Jika terdapat kesamaan pandangan antara Jaksa dan Hakim, maka Hakim akan menjatuhkan pidana sama dengan tuntutan Jaksa. Tetapi jika tidak terdapat kesamaan pandangan, maka hakim akan menjatuhkan pidana di bawah atau lebih ringan dari dakwaan Jaksa. Sebaliknya hakim bisa menjatuhkan pidana melebihi tuntutan Jaksa. Hakim dalam menjatuhkan pidana akan mengacu pada hal-hal yang terbukti dan berdasrkan alat bukti di pengadilan, sesuai Pasal 183 KUHAP. Hakim dalam menjatuhkan putusan akan memilih pendapat hakim yang paling menguntungkan bagi terdakwa. Hal ini sesuai dengan Pasal 182 ayat (6) KUHAP. Hakim juga melihat faktor yang mempengaruhi pelaku melakukan tindak pidana. Hal tersebut adalah watak pribadi, tekanan jiwa, motif pelaku dan keadaan lingkungan sekitar tempat tinggal. ${ }^{29}$

Berkenaan dengan itu, peneliti juga menganalisis bahwa untuk membimbing tingkah laku anak maka keluarga memiliki peran sentral yang cukup penting. Hasil penelitian yang dilakukan menunjukkan bahwa ternyata kontrol diri anak mempunyai peranan penting dalam mendorong kejahatan oleh anak, sehingga pola asuh orangtua yang efektif di masa kanakkanak (penerapan strategi yang konsisten, berpusat pada anak dan tidak aversif) berhubungan dengan dicapainya pengaturan diri oleh anak. Selanjutnya, dengan memiliki pola asuh orangtua yang efektif sebagai atribut internal akan berpengaruh pada menurunnya tindak kejahatan oleh anak. Lingkungan keluarga berperan serta dalam membentuk kepribadian anak.

Bimbingan anak dalam keluarga dan aktivitas dalam lingkungan keluarga yang kurang komunikatif dan harmonis merupakan salah satu faktor pendukung dalam diri anak untuk

\footnotetext{
${ }^{27}$ Hasil wawancara dengan Ajeng P., Penyidik PPA Polres Lampung Tengah tanggal 7 November 2015, pukul 13.20 WIB

${ }^{28}$ Hasil wawancara dengan Lukman selaku Koordinator Penanganan Kasus dan Pengorganisiran LSM LADA Bandar Lampung tanggal 26 Oktober 2018, pukul 14.15 WIB

${ }^{29}$ Hasil wawancara dengan Eddy Rifai selaku Dosen Bagian Hukum Pidana Fakultas Hukum Universitas Lampung tanggal 29 Oktober 2018, pukul 10.30 WIB
} 
membentuk kepribadian yang kurang baik. Dalam hal ini, perbuatan pelaku atas tindak pidana kesusilaan secara berlanjut pada dasarnya termasuk melawan hukum karena telah melanggar undang-undang namun secara psikologis anak tersebut tidak mengetahui dan mengerti atas perbuatannya. Dalam memberikan pertimbangan, maka penegak hukum pun melihat dan mempertimbangkan berbagai aspek baik aspek hukum, psikologis, dan kemanusiaan. Melihat pelaku yang masih anak dibawah umur maka hal ini tentunya mensyaratkan mengenai bentuk rehabilitasi dan pembinaan khusus terhadap pelaku untuk dapat untuk mengembangkan kontrol diri.

Tindak pidana kesusilaan secara berlanjut jelas bersifat melawan hukum, karena perbuatan tersebut sudah memenuhi rumusan delik yang ada dalam Pasal 81 Ayat (2) Undang-Undang Nomor 35 Tahun 2014 jo Pasal 64 Ayat (1) KUHP. Serta termasuk ke dalam unsur kesengajaan, karena perbuatannya dimulai dengan niat pelaku dan si pelaku dalam melakukan perbuatannya mempunyai tujuan dan maksud yang jelas. Di sini jelas sekali bahwa anak sebagai pelaku kejahatan kesusilaan secara berlanjut dapat dipidana atas perbuatannya guna mempertanggungjawabkan perbuatannya karena seseorang dapat dikatakan bertanggung jawab apabila jiwanya sehat, mampu mengetahui bahwa perbuatannya bertentangan dengan hukum, serta mampu memenuhi kehendak sesuai kesadarannya.

Berdasarkan uraian di atas, peneliti tidak sependapat dengan pertimbangan majelis hakim yang ditinjau dari aspek pertanggungjawaban pidananya telah memutus pelaku dengan dijatuhi vonis oleh Majelis Hakim sepakat Menjatuhkan Tindakan berupa mengembalikan Terdakwa Bayu Setiangga Bin Supriyanto kepada Orang Tuanya untuk dibina dan dididik dengan alasan bahwa hasil pemeriksaan disidang pengadilan menyatakan bahwa terdakwa telah merusak masa depan korban. Penerapan sanksi pidana terhadap anak pelaku tindak pidana kesusilaan secara berlanjut dalam kasus pada Pengadilan Negeri Kalianda Penetapan Nomor: 01/Pid.Sus-Anak/2015/PN.Kla dapat dimintai pertanggungjawabannya, sesuai dengan unsur-unsur tindak pidana, yaitu sehat jiwanya, mengetahui bahwa perbuatannya bertentangan dengan hukum serta mampu mengetahui kehendak sesuai kesadarannya, sehingga dapat dipidana oleh Hakim. Tujuan Majelis Hakim telah Menjatuhkan Tindakan berupa mengembalikan Terdakwa Bayu Setiangga Bin Supriyanto kepada Orang Tuanya untuk dibina dan dididik sesuai dengan konsep tujuan pemidanaan yakni bukanlah suatu pembalasan melainkan pembinaan bagi terdakwa yang telah berbuat salah dan agar dapat mempertanggungjawabkan perbuatannya.

Sanski Tindakan berupa mengembalikan Terdakwa Bayu Setiangga Bin Supriyanto kepada Orang Tuanya untuk dibina dan dididik dalam kasus pada Pengadilan Negeri Kalianda Putusan Nomor: 01/Pid.Sus-Anak/2015/PN.Kla yakni anak sebagai pelaku tindak pidana kesusilaan secara berlanjut tersebut memang sudah memenuhi ketentuan Pasal 81 Ayat (2) Undang-Undang Nomor 35 Tahun 2014 tentang Perubahan Atas Undang-Undang Nomor 23 Tahun 2002 tentang Perlindungan Anak, namun terkadang putusan hakim tidak pernah mencapai pidana yang maksimum seperti yang diancamkan dalam undang-undang. Sanksi yang dijatuhkan terhadap pelaku dinilai belum tepat jika dilihat dari akibat perbuatan yang dilakukan pelaku tindak pidana kesusilaan secara berlanjut sehingga belum sepenuhnya memenuhi rasa keadilan bagi korban.

Putusan Hakim yang tidak mencapai pidana maksimum seperti yang diancamkan dalam undang-undang, perbuatan terdakwa dalam perkara tersebut juga merupakan perbuatan berulang yang tidak hanya 1 (satu) kali dilakukan namun Majelis Hakim Menjatuhkan Tindakan berupa mengembalikan Terdakwa Bayu Setiangga Bin Supriyanto kepada Orang Tuanya untuk dibina dan dididik. Hal ini tentu menimbulkan permasalahan dalam pemidanaan dalam mencapai keadilan yang menginginkan pelaku tindak pidana kesusilaan 
secara berlanjut diberikan hukuman yang seimbang dengan akibat perbuatannya, hal inilah peranan Hakim sangat penting sebagai penengah di antara pihak-pihak yang berperkara.

Problem sosial yang terjadi juga bahwa penjatuhan pidana terhadap tindak pidana kesusilaan secara berlanjut dapat menimbulkan ketidakadilan secara substantif maupun prosedural baik bagi korban maupun keluarganya hal ini karena tindak pidana kesusilaan secara berlanjut sangat berdampak buruk bagi perkembangan korban terlebih bahwa korban masih pelajar dan memiliki masa depan namun terhenti akibat perbuatan terdakwa. Tuntutan Jaksa yang menuntut selama 7 (tujuh) tahun pidana penjara dan 6 (enam) bulan dengan dikurangi seluruhnya masa telah dijalaninya dengan perintah terdakwa tetap ditahan dan didenda sebesar Rp 60.000.000,- (enam puluh juta rupiah) subsidair 3 (tiga) bulan kurungan namun Majelis Hakim hanya memberikan vonis Menjatuhkan Tindakan berupa mengembalikan Terdakwa Bayu Setiangga Bin Supriyanto kepada Orang Tuanya untuk dibina dan dididik. Hal ini tentunya melukai rasa keadilan bagi korban dan keluarganya karena selain mengalami derita, depresi, dan trauma yang besar di masa depan korban juga menanggung beban sosial. Pidana ini dirasakan terlalu ringan bila dibandingkan dengan derita, depresi, dan trauma yang besar di masa depan korban.

\section{Penutup}

Kesimpulan dari penelitian ini adalah:

1. Pertanggungjawaban pidana terhadap anak sebagai pelaku kejahatan kesusilaan secara berlanjut yakni dilaksanakan dengan Tindakan berupa mengembalikan Terdakwa kepada Orang Tuanya untuk dibina dan dididik. Tujuan pemidanaan berorientasi mengutamakan kepentingan terbaik anak terintegrasi ke dalam sistem dan model peradilan pidana anak, mendorong terintegrasinya ke dalam norma hukum positif dan penegakkan hukum anak. Tujuan pemidanaan bukanlah pada penghukuman, tetapi perbaikan kondisi, pemeliharaan dan perlindungan anak.

2. Dasar pertimbangan hukum hakim dalam menjatuhkan sanksi pidana adalah dakwaan Jaksa, tujuan pemidanaan, hal-hal yang meringankan dan memberatkan, serta menerapkan beberapa teori-teori tujuan hukum yakni kepastian hukum, kemanfaatan dan keadilan hukum.

Saran dalam penelitian ini yakni:

1. Pertanggungjawaban pidana terhadap anak sebagai pelaku kejahatan kesusilaan secara berlanjut yakni terdakwa Bayu Setiangga Bin Supriyanto sebaiknya tidak hanya menjalani pidana tindakan secara hukum namun juga harus bertanggungjawab secara sosial maupun materiil kepada korban maupun keluarganya.

2. Hakim sebaiknya lebih memaksimalkan pidana yang dijatuhkan kepada setiap pelaku kejahatan terhadap anak, mengingat bahwa kejahatan terhadap anak di Indonesia terus meningkat sehingga hal ini dapat menjadi salah satu pertimbangan hakim dalam memberikan pidana maksimum terhadap pelaku tindak pidana kesusilaan terhadap anak. Sanksi hukuman yang maksimum juga mendorong kebijakan hukum tentang sanksi hukuman tambahan berupa hukuman pengebirian selain pidana penjara yang saat ini sedang dibahas oleh Presiden dan DPR bersama KPAI. Perbuatan pelaku tindak pidana kesusilaan terhadap anak seperti dalam Putusan Pengadilan Negeri Kalianda Nomor : 01/Pid.Sus-Anak/2015/PN.Kla mengakibatkan kerugian psikis dan telah merusak masa depan korban. Hakim diharapkan lebih cermat dalam mempertimbangkan sebuah perkara baik dengan logika penalaran hukum maupun dengan nilai-nilai keadilan berdasarkan hati nuraninya agar putusan yang dijatuhkan tidak menimbulkan kedzoliman bagi pihak yang berperkara. 


\section{Daftar Pustaka}

A. Buku

Gultom, Maidin. (2008). Perlindungan Hukum Terhadap Anak dalam Sistem Peradilan Pidana Anak di Indonesia. Bandung: Refika Aditama.

Herlina, Apong dkk. (2004). Perlindungan terhadap Anak yang Berhadapan dengan Hukum, Buku Saku untuk Polisi. Jakarta: Unicef.

Lamintang, P.A.F. (1997). Dasar-Dasar Hukum Pidana Indonesia. Bandung: Citra Aditya Bakti. Saleh, Roeslan. (1987). Pertanggungjawaban Hukum Pidana, Jakarta: Aksara Baru.

Setiady, Tolib. (2010). Pokok-Pokok Hukum Penitensier Anak Indonesia. Bandung: Alfabeta.

Soekanto, Soerjono. (1986). Pengantar Penelitian Hukum. Jakarta: UI Press.

Soetodjo, Wagiati. (2006). Hukum Pidana Anak. Bandung: Refika Editama.

Wadong, M. Hassan. (2012). Advokasi dan Hukum Perlindungan Anak. Jakarta: Grasindo.

Widoyanti, Sri. (1984). Anak dan Wanita dalam Hukum. Jakarta: Pradya Paramita.

B. Jurnal

Afifah, Wiwik. "Pertanggungjawaban Pidana Anak Konflik Hukum." DIH, Jurnal Ilmu Hukum Vol. 10, No. 19, Pebruari 2014: 48-62 https://media.neliti.com/media/publications/240062pertanggungjawaban-pidana-anak-konflik-h-1431e76f.pdf.

Airlangga, Shandi Patria. "Hakikat Penguasa Dalam Negara Hukum Demokratis The Nature Of The Authorities In A Democratic Rule Of Law." Cepalo 3, no. 1 September 17, 2019: 1-10. https://doi.org/10.25041/cepalo.v3no1.1783.

Andrianto, Hendricus, and Nur Rochaeti. "Implementasi Diversi Terhadap Anak Yang Berhadapan Dengan Hukum Di Polres Pati." DIPONEGORO LAW JOURNAL. Vol. 5. Program Studi S1 Ilmu Hukum, Fakultas Hukum, Universitas Diponegoro, July 11, 2016: 110, https://ejournal3.undip.ac.id/index.php/dlr/article/view/12535.

Arliman, Laurensius, S Stih, Padang; Aphtn-Han, and Sumatera Barat. "Reformasi Penegakan Hukum Kekerasan Seksual Terhadap Anak Sebagai Bentuk Perlindungan Anak Berkelanjutan Reform Of Law Enforcement Of Sexual Violence To Children As The Form Of Sustainable Children Protection." Kanun Jurnal Ilmu Hukum 19, no. 2, August 27, 2011 : 305-26. http://www.jurnal.unsyiah.ac.id/kanun.

Arliman S, Larensius. "Pendidikan Paralegal Kepada Masyarakat Sebagai Bentuk Perlindungan Anak Yang Berkelanjutan." UIR LAW REVIEW 1, no. 01 April 25, 2017: 63-76. https://doi.org/10.25299/ulr.2017.1.01.153.

Hutahaean, Bilher. "Penerapan Sanksi Pidana Bagi Pelaku Tindak Pidana Anak." Jurnal Yudisial, vol. 6, (March 11, 2013): 64-79, https://doi.org/10.29123/JY.V6I1.119.

Made, Ni, Ita Ariani, Ni Putu, Rai Yuliartini, Dewa Gede, and Sudika Mangku. "Implementasi Undang-Undang Nomor 11 Tahun 2012 Tentang Sistem Peradilan Pidana Anak Terhadap Curanmor Yang Dilakukan Oleh Anak Di Kabupaten Buleleng (Studi Kasus Perkara Nomor : B/346/2016/Reskrim)." Jurnal Komunitas Yustisia. Vol. 2, February 28, 2019: 1-11, https://bulelengkab.bps.go.id.

Mulyadi, H Dudung. "Perlindungan Hukum Bagi Anak Korban Perkosaan Dalam Peradilan Anak." Jurnal Ilmiah Galuh Justisi. Vol. 6, November 19, 2018: 170-183 https://jurnal.unigal.ac.id/index.php/galuhjustisi/article/view/1712.

Musfiroh, Mayadina Rohmi. "Pernikahan Dini Dan Upaya Perlindungan Anak Di Indonesia." De Jure : Jurnal Hukum dan Syari'ah Vol. 8, no. 2, 2016: 64-73. https://doi.org/10.18860/jfsh.v6i1.3192.

Nugroho, Okky Chahyo. "Peran Balai Pemasyarakatan Pada Sistem Peradilan Pidana Anak Ditinjau Dalam Perspektif Hak Asasi Manusia." Jurnal HAM Vol. 8, no. 2, December 15, 2017: 161-74. https://ejournal.balitbangham.go.id/index.php/ham/article/view/356.

Nyoman, Krisna Yudha, Anak Agung, and Sri Utari. "Perlindungan Hukum Terhadap Anak Sebagai Pelaku Tindak Pidana Narkotika *." Kertha Wicara: Journal Ilmu Hukum. Vol. 9, January 13, 2020: 1-115 https://ojs.unud.ac.id/index.php/kerthawicara/article/view/53868. 
Aghisni Kasrota Rizki., "Pertimbangan Dasar Hakim Pengadilan Militer Dalam Menjatuhkan Putusan Di Mahkamah Militer Ii-10 Semarang)." ULJ. vol. 4, No. 1, 2015: 35-55 https://doi.org/10.15294/ULJ.V4I1.7270.

Pribadi, Dony. "Perlindungan Terhadap Anak Berhadapan Dengan Hukum." Jurnal Hukum Volkgeist 3, no. 1 December 14, 2018: 15-28. https://doi.org/10.35326/volkgeist.v3i1.110.

Widodo, Selamat. "Diversi Sebagai Bentuk Perlindungan Hak Asasi Anak Yang Berhadapan Dengan Hukum (Studi Di Pengadilan Negeri Purwokerto).” Jurnal Kosmik Hukum 17, no. 1, January 30, 2017: 50-61 https://doi.org/10.30595/kosmikhukum.v17i1.2318.

Zai, Ariyunus, Taufik Siregar, and Dedy irsan. "Perlindungan Hukum Terhadap Anak Yang Berhadapan Dengan Hukum Dalam Sistem Peradilan Anak (Studi Pada Wilayah Hukum Polres Nias)." JURNAL MERCATORIA. Vol. 4, December 1, 2011: 86-103, http://www.ojs.uma.ac.id/index.php/mercatoria/article/view/610.

C. Undang-Undang

Undang-Undang Dasar Republik Indonesia Tahun 1945.

Undang-Undang Nomor 1 Tahun 1946 jo Undang-Undang Nomor 73 Tahun 1958 tentang Pemberlakuan Kitab Undang-Undang Hukum Pidana (KUHP).

Undang-Undang Nomor 11 Tahun 2012 tentang Sistem Peradilan Pidana Anak.

Undang-Undang Nomor 16 Tahun 2004 tentang Kejaksaan RI.

Undang-Undang Nomor 2 Tahun 2002 tentang Kepolisian Negara RI.

Undang-Undang Nomor 23 Tahun 2002 jo Undang-Undang Nomor 35 Tahun 2014 tentang Perlindungan Anak.

Undang-Undang Nomor 39 Tahun 1999 tentang Hak Asasi Manusia.

Undang-Undang Nomor 4 Tahun 1979 tentang Kesejahteraan Anak.

Undang-Undang Nomor 48 Tahun 2009 tentang Kekuasaan Kehakiman RI.

Undang-Undang Nomor 8 Tahun 1981 tentang Hukum Acara Pidana (KUHAP). 